\title{
Antibacterial in vitro of effect urtica dioica and piper angustifolium in alpacas (vicugna pacus) with diarrheal enteropathies
}

\begin{abstract}
The study was antibacterial to the effect of Urtica dioica and Piper angustifolium in vitro in alpacas with enteropathy. 120 faecal samples from 90 calves born 15 days alpacas were taken. Escherichia coli, Clostridium $s p$ were obtained through biochemical tests. The antibacterial susceptibility was evaluated in three groups: Matico G1, G2 and G3Nettle Witness-Enrofloxacin concentrations 10 and $5 \%$ by disk diffusion method and method Optical turbidimetry. The MIC and MBC was significant $(\mathrm{P}<0.01)$ Escherichia coli in groups G1 (Sensitive $=29.3 \pm 0.2 \mathrm{a}$, Intermediate $=15.2 \pm 0.3 \mathrm{a}$, resistance $=0.0$ ) and G2 (Sensitive $=26,1 \pm 0.4 \mathrm{ab}$, Intermediate $=16.2 \pm 0.2 \mathrm{a}$ resistance $=0.0)$ and $\mathrm{CMB} \mathrm{G1}(0.1 \mathrm{a} \pm 22.0$, $21.0 \pm 1.3 \mathrm{a}), \mathrm{G} 2(0.5 \mathrm{ab} \pm 37.0,39.0 \pm 0.2 \mathrm{ab})$ against group G3 (=20.2 $\pm 0.2 \mathrm{ac}$ Sensitive, Intermediate $=15.1 \pm 0.1 \mathrm{ac}$, Resistance $=10.4 \pm 0.3 \mathrm{c})$ and $\mathrm{CMB}(0.4 \mathrm{ac} \pm 420,460 \pm 1.6 \mathrm{c})$, Urtica dioica and Piper angustifolium demonstrate antibacterial effectiveness in alpacas of diarrheal enteropathies.
\end{abstract}

Keywords: alpacas, enteropathies, piper angustifolium, urtica dioica
Volume 5 Issue 2 - 2018

\author{
Carhuapoma DV,' Mayhua MP,'2 Valencia MN, ${ }^{2}$ \\ Lizana $\mathrm{HE}^{3}$ \\ 'Center for Multidisciplinary Scientific Research of the National \\ University of Huancavelica, University City of Paturpampa s/n, \\ Peru \\ ${ }^{2}$ National University of Huancavelica of EAP, Ciudad \\ Universitaria de Paturpampa, Peru \\ ${ }^{3}$ Animal Health Laboratory EAP, Zootechnics of the National \\ University of Huancavelica, University City of Paturpampa, Peru
}

Correspondence: Carhuapoma DV, Center for Multidisciplinary Scientific Research of the National University of Huancavelica. University City of Paturpampa s / n. Huancavelica, Peru, Email yachayruacc@hotmail.com

Received: January 23, 2018 | Published: April 26, 2018

\section{Introduction}

The domestic South American Camelids, the alpaca and lallama represent a strategic natural resource, of great social, economic and ecological importance in the life of the high Andean population of Peru and Bolivia and to a lesser degree Argentina, Ecuador and Chile, mainly associated with the production of fibre and meat. ${ }^{1}$ About $90 \%$ of the alpacas are in the hands of small producers and peasant communities. ${ }^{2,3}$ In these places, the exploitation is carried out following traditional production systems, lacking adequate technologies and having high mortality rates of alpaca neonates, reaching up to $70 \%{ }^{4}$ the Clostridium perfringens and enteropathogenic Escherichia coli are of greater sanitary and economic impact in the alpaca production ${ }^{5}$ because they are causal agents of pathologies that present with intestinal dysfunction, generating the neonatal diarrheal complex in the alpacas ${ }^{6}$ and there are no veterinary or related products to date that could be effective for the treatment of the neonatal diarrheal complex in South American camelids, ${ }^{1}$ this led us to study the antibacterial effect of Urtica dioica and Piper angustifolium in vitro on alpacas with diarrheal enteropathies. Ethanolic del extract of Urtica dioica and Piper angustifolium in vivo as antibacterial This would be an alternative to reduce the high mortality levels of alpaca neonates because they are excellent antibacterials for the neonatal diarrhoea complexes of alpacas and stimulators to reduce the immunological resistance of the causative agents of diarrheal bacterial pathologies.

\section{Materials and methods}

The study was carried out in the Central Animal Health Area Research Laboratory of the National University of Huancavelica-Peru, the extraction of the extractosetanolics was carried out according to the protocol dissertated by Hernández ${ }^{7}$ which consisted of: collection, selection and drying, pulverization, weighing, addition of solvents, stirring, 2nd addition of solvent, casting, filtration, solvent removal, resuspension and sterilization. 120 stool samples were collected from 90 alpaca pups with enteropathies. The samples were taken by the rectal swab method and suspended in Stuart transport medium. For the isolation and identification of the microorganisms, biochemical tests were used using selective media of Macconkey agar and TNS agar, the study groups were: G1-Matico, G2-Ortigay G3 ControlEnrofloxacin at a concentration of 5 and $10 \%$. The antibacterial active ingredient was determined by the disk diffusion method [Minimum Inhibitory Concentration (MIC)] and optical method of Turbidimetry (McFarland and absorbance by spectrophotometry) described by Aldana $^{8}$ [Minimum Bacterial Concentration (CMB)]. Analysis of variance and the Tukey test $(\mathrm{P}<0.01)$ using the SPSS v. twenty.

\section{Result and discussions}

The significant antibacterial effect of $\mathrm{CMB}(\mathrm{P}<0.01)$ showed the G1 groups (22.0 $\pm 0.1 \mathrm{a}, 21.0 \pm 1.3 \mathrm{a}), \mathrm{G} 2(37.0 \pm 0.5 \mathrm{ab}, 39.0 \pm 0.2 \mathrm{ab})$ that the group G3 $(42.0 \pm 0.4 \mathrm{ac}, 46.0 \pm 1.6 \mathrm{c})$, there are still significant differences in the groups $\mathrm{G} 1$ and $\mathrm{G} 2(\mathrm{P}<0.01)$ in the concentrations of 5 and $10 \%$, Escherichia Coli being very sensitive that the Clostridium $s p$ (Table 1). The antibacterial effectiveness demonstrated by nettle and matico, is due to the fact that these plants contain components of fluoroquinolones and flavonoids, ${ }^{9}$ which are based on their mechanism of action in inhibiting the enzyme DNA gyrase de enterobacteria. Thanks to these mechanisms, inflammatory inhibition occurs. Cell tissue regeneration. ${ }^{10}$ A study conducted by Maravi ${ }^{11}$ with samples of vocal shrouds of patients with conopharynx, reported the CMB (0.3562 \pm 1.6$)$ on Streptococcus mutans with Oregano and with Lactobacillus acidophilus (0, 4812 \pm 1.2$)$ and Candida albicans $(0.3922 \pm 1.0)$ with Hierba Luisa; Ocares ${ }^{12}$ reports that the dichloromethane extract of Rumex palustris showed antimicrobial activity against Staphylococcus aureus and Enterococcus faecalis 
at $\mathrm{CMB}$ of $1000 \mu \mathrm{g} / \mathrm{ml}$, being inactive against Escherichia coli and Pseudomonas aeruginosa, and there are no studies aimed at animal health the ethnopharmacology of there its importance of the study.

The CMI was significant $(\mathrm{P}<0.01)$ in the $\mathrm{G} 1$ group (Sensitive $=29.3 \pm 0.2 \mathrm{a}$, Intermediate $=15.2 \pm 0.3 \mathrm{a}$, Resistant $=0.0$ ) and $\mathrm{G} 2$ (Sensitive $=26.1 \pm 0.4 \mathrm{ab}$, Intermediate $=16.2 \pm 0.2 \mathrm{a}$ Resistant $=0.0$, ) than the group alG3 (Sensitive $=20.2 \pm 0.2 \mathrm{ac}$, Intermediate $=15.1 \pm 0.1 \mathrm{ac}$, Resistant $=10.4 \pm 0.3 \mathrm{c}$ ) and greater sensitivity showed in Escherichia
Coli than in Clostridium sp (Table 2), because the Dioica and Piper angustifolium have antibacterial components that inhibit cell wall synthesis and nucleic acids causing cell destruction and degradation. ${ }^{13}$ Becerra ${ }^{14}$ use ethanolic extract of Eucalyptus globulus at concentrations of: $100 \%, 50 \%, 25 \%, 12.5,6.25 \%$ and $3.13 \%$ against Lactobacillus sp, finding the MIC at $3.13 \%$ and the $6.25 \% \mathrm{WBC}$ and the aqueous extract did not present an antibacterial effect on the strain of Lactobacillus sp.

Table I Measures and standard deviation of the minimum bacterial concentration (CMB) of Escherichia coli and Clostridium sp (650nm)

\begin{tabular}{|c|c|c|c|c|c|c|c|}
\hline Groups & Concen & Doses & $\mathbf{N}$ & \multicolumn{2}{|c|}{ Escherichia coli } & \multicolumn{2}{|l|}{ Clostridium sp } \\
\hline \multirow{3}{*}{ G1 EE Matico } & \multirow[b]{2}{*}{$10 \%$} & \multirow[b]{2}{*}{$10 \mathrm{ML}$} & 120 & $\begin{array}{l}\text { Pre } \\
\text { absorbance } \\
(\mathbf{n m})\end{array}$ & $\begin{array}{l}\text { Post } \\
\text { absorbance } \\
(\mathrm{nm})\end{array}$ & $\begin{array}{l}\text { Pre absorbance } \\
(\mathrm{nm})\end{array}$ & $\begin{array}{l}\text { Post absorbance } \\
(\mathrm{nm})\end{array}$ \\
\hline & & & 20 & $66,0 \pm 0,2 \mathrm{a}$ & $22,0 \pm 0,1 \mathrm{a}$ & $64,0 \pm 1,2 \mathrm{a}$ & $21,0 \pm 1,3 \mathrm{a}$ \\
\hline & $5 \%$ & $5 \mathrm{ML}$ & 20 & $64,0 \pm 0,8 b$ & $28,0 \pm 0,3 b$ & $58,0 \pm 0,7 \mathrm{~b}$ & $28,0 \pm 0,5 b$ \\
\hline \multirow{2}{*}{ G2 EE Ortiga } & $10 \%$ & $10 \mathrm{ML}$ & 20 & $65,0 \pm 0,4 \mathrm{ab}$ & $37,0 \pm 0,5 \mathrm{ab}$ & $62,0 \pm 1,3 \mathrm{ab}$ & $39,0 \pm 0,2 \mathrm{ab}$ \\
\hline & $5 \%$ & $5 \mathrm{ML}$ & 20 & $59,0 \pm 0,1 \mathrm{~b}$ & $34,0 \pm 0,2 b$ & $62,0 \pm 0,1 \mathrm{ab}$ & $37,0 \pm 0,6 \mathrm{ab}$ \\
\hline \multirow{2}{*}{ G3 Enrofloxacino } & $10 \%$ & $10 \mathrm{ML}$ & 20 & $61,0 \pm 0,5 \mathrm{c}$ & $42,0 \pm 0,4 \mathrm{ac}$ & $67,0 \pm 0,6 \mathrm{c}$ & $46,0 \pm 1,6 \mathrm{c}$ \\
\hline & $5 \%$ & $5 \mathrm{ML}$ & 20 & $63,0 \pm 0,6 \mathrm{c}$ & $45,0 \pm 0,1 \mathrm{c}$ & $66,0 \pm 0,4 \mathrm{ac}$ & $49,0 \pm 0,4 \mathrm{ac}$ \\
\hline
\end{tabular}

$\mathrm{a} \neq \mathrm{b}, \mathrm{b} \neq \mathrm{c}$ to Tukey prueba $(\mathrm{P}<0.0 \mathrm{I})$

Table 2 Measures and standard deviation of minimum inhibitory concentration (MIC) Escherichia coli and Clostridium sp

\begin{tabular}{|c|c|c|c|c|c|c|c|c|}
\hline \multirow[t]{2}{*}{ Treatments } & \multirow[t]{2}{*}{ Concen $\mu \mathbf{L}$} & \multirow{2}{*}{$\begin{array}{l}N \\
120\end{array}$} & \multicolumn{3}{|c|}{$\begin{array}{l}\text { Escherichia coli } \\
(\mathrm{R} \leq 14, \mathrm{I} 14 \geq 18, \mathrm{~S} \geq 18)\end{array}$} & \multicolumn{3}{|c|}{$\begin{array}{l}\text { Clostridium } s p \\
(\mathrm{R} \leq 14, \mathrm{I} 14 \geq 18, \mathrm{~S} \geq 18)\end{array}$} \\
\hline & & & $\mathbf{S}$ & I & $\mathbf{R}$ & $\mathbf{S}$ & I & $\mathbf{R}$ \\
\hline \multirow{2}{*}{ G1 EE Matico } & 10 & 20 & $29,3 \pm 0.2 \mathrm{a}$ & $15,2 \pm 0.3 \mathrm{a}$ & 0,0 & $27,3 \pm 0.1 \mathrm{a}$ & $15,2 \pm 0.4 \mathrm{a}$ & 0,0 \\
\hline & 5 & 20 & $28,6 \pm 0.2 b$ & $14,4 \pm 0.5 b$ & 0,0 & $26,6 \pm 0.2 b$ & $14,4 \pm 0.5 b$ & 0,0 \\
\hline \multirow{2}{*}{ G2 EE Ortiga } & 10 & 20 & $26,1 \pm 0.4 \mathrm{ab}$ & $16,2 \pm 0.2 \mathrm{a}$ & 0,0 & $23,1 \pm 0.3 \mathrm{ab}$ & $17,2 \pm 0.2 \mathrm{a}$ & 0,0 \\
\hline & 5 & 20 & $18,5 \pm 0.1 b$ & $14,1 \pm 0.6 b$ & 0,0 & $19,5 \pm 0.3 b$ & $16,1 \pm 0.6 b$ & 0,0 \\
\hline \multirow{2}{*}{ G3 Enrofloxacino } & 10 & 20 & $20,2 \pm 0.2 \mathrm{ac}$ & $15,1 \pm 0.1 \mathrm{ac}$ & $10,4 \pm 0.3 \mathrm{c}$ & $22,3 \pm 0.5 \mathrm{ac}$ & $18,1 \pm 0.1 \mathrm{ac}$ & $13,4 \pm 0.6 \mathrm{c}$ \\
\hline & 5 & 20 & $19,0 \pm 0.4 \mathrm{c}$ & $16,8 \pm 0.1 \mathrm{ac}$ & $11,0 \pm 0.3 \mathrm{ac}$ & $18,0 \pm 0.4 \mathrm{c}$ & $14,8 \pm 0.3 \mathrm{ac}$ & $11,2 \pm 0.2 \mathrm{ac}$ \\
\hline
\end{tabular}

$a \neq b, b \neq c$ to the Tukey prubeba $(p<0.0 I)$

\section{Conclusion}

Urtica dioica and Piper angustifolium showed antibacterial effectiveness in vitro in alpacas with diarrheal enteropathies.

\section{Acknowledgements}

To the executive administrator of the Central Research Laboratory of the National University of Huancavelica and the Communal Farm of the Peasant Community of Santa Bárbara-Huancavelica for providing the facilities for the execution of this study.

\section{Conflict of interest}

The authors declare no conflict of interest.

\section{References}

1. Ortiz S. Evaluación de algunos métodos de control de la mortalidad en crias de alpaca (Lama pacos) en explotaciones familiares. Tesis de Médico
Veterinario. Lima, Peru: Universidad Nacional Mayor de San Marcos; 2011:58.

2. Ramírez A. Colibacilosis entérica en crías de Alpacas. In: Avances sobre Investigación en Salud Animal Camélidos Sudamericanos. UNMSM. Bol Div. 1990;23:64.

3. More J, Manchego A, Sandoval N, et al. Detección genómica y expresión de péptidos antimicrobianos ( $\alpha$ - y $\beta$-defensinas) en mucosa intestinal de crías de alpaca (Vicugna pacos). Rev Inv Vet Perú. 2011;22:324-335.

4. Siuce J, Alberto Manchego S, Nieves Sandoval C, et al. Expresión de Defensinas en Yeyuno de Crías de Alpacas (Vicugna pacos) con Enteropatías. Rev Inv Vet Perú. 2015;26(2):317-327.

5. Oha R. Anatomía patológica de las diarreas infecciosas en crías de alpaca (Lama pacos) en la SAIS Aricoma Ltda.57. Tesis de Médico Veterinario y Zootecnista. Facultad de Medicina Veterinaria y Zootecnia. Puno: Univ Nacional del Altiplano; 2012:79.

6. Rosadio A, Yaya K, Véliz P, et al. Efecto protector de una vacuna 
polivalente anticlostridial sobre la mortalidad neonatal en alpacas. Rev Inv Vet Perú. 2012;23(3):299-306.

7. Hernández S. Determinación de la actividad antibacteriana in vitro de los extractos de Romero (Rosmarinus officinalis) y Tomillo (Thymus vulgaris). Tesis de Grado Previa a la obtención el Titulo: Bioquímico Farmacéutico. Escuela Superior Politécnica de Chimborazo Facultad de Ciencias Escuela de Bioquímica y Farmacia. Riobamba-Ecuador. 2010:46-52.

8. Aldana J, Duque J, Hidalgo I. Asociación del estreptococos mutans y lactobacilos con la caries en niños. Rev Cubana Estomatol. 2007;44(4).

9. Giménez A, Flores E, Jiménez, et al. Estudio Fitoquímico de Catorce especies del Género Piper con actividad anti fúngica y/o Leishmanicida in vitro. Revista Biofarbo. 2009;(8):9-16.

10. Chopra I, Roberts M. Tetracycline antibiotics: Mode of action, applications, molecular biology and epidemiology of bacterial resistance. Microbiol Mol Biol Rev. 2011;65(2):232-260.

11. Maraví G. Efecto Antibacteriano y Anti fúngico del Aceite Esencial de: Menta piperita (Menta), Origanum vulgare (Orégano) y Cymbopogon citratus (Hierba Luisa) sobre Streptococcus mutans ATCC 25175, Lactobacillus acidophilus ATCC 10746 y Cándida albicans ATCC 90028”. Tesis Para Optar el Título de Cirujano Dentista. Lima, Perú: Universidad Privada Norbert Wiener Facultad de Ciencias de la Salud Escuela Académica Profesional de Odontología; 2012:18-28.
12. Ocares M. Acción antimicrobiana de extractos crudos de especies de plantas nativas sobre Escherichia coli y Salmonella sp. Memoria presentada para optar al Título de Ingeniero en Alimentos. Universidad Austral de Chile Facultad de Ciencias Agrarias Escuela de Ingeniería en Alimentos, Chile; 2012:204.

13. Matute M. Evaluación in vitro del Extracto de Piper angustifolium (Matico) y La Clorhexidina como Antisépticos Bucales. Tesis Para Obtener el Título Profesional de Cirujano Dentista. Lima Perú: Universidad Nacional Federico Villarreal Facultad de Odontología; 2009:88-112.

14. Becerra K. Efecto Antibacteriano In Vitro de los Extractos Acuosos y Etanólico de Eucallyptus globulus L (Eucalipto) en diferentes concentraciones sobre Cepa de Lactobacillus sp. Tesis para Optar Título Profesional en Cirujano Dentista. Universidad Privada Antenor Orrego. Facultad de Medicina Human. Trujillo, Perú: Escuela Profesional de Estomatología; 2010:12-18. 